\title{
Chronic transmural bronchiolitis: a non-specific lesion of small airways
}

\author{
C Edwards, R Cayton, R Bryan
}

\begin{abstract}
Aims: To investigate nine patients with histological changes at open lung biopsy compatible with so-called "small airways disease"; to define these changes and distinguish them from other types of bronchiolitis; and to correlate them with clinical features, respiratory physiology, and other laboratory investigations.
\end{abstract}

Methods: The open biopsy sections and the clinical records were reviewed.

Results: There was chronic inflammation of the walls of centri-acinar respiratory bronchioles and peribronchiolar alveoli. Peripheral alveoli of affected acini were spared. Although lumens were narrowed and distorted, obstruction by granulation tissue plugs was not a feature. Clinical backgrounds included Hodgkin's disease, yellow nail syndrome, sicca syndrome, asthma and psoriasis. The main presenting symptoms were cough, dyspnoea and wheeze, often associated with basal crackles and basal shadowing. There was no consistent immunological or haematological abnormality. Sputum culture was negative in six patients, and a variety of organisms were cultured from three others. In most cases respiratory function tests revealed an irreversible obstructive defect (combined in some cases with a restrictive defect), gas trapping, and well preserved gas transfer. Lung volumes were normal. Bronchodilators, with steroids and azathioprine in more seriously affected patients, stabilised the disease process.

Conclusions: The histological changes may be distinguished from bronchiolitis obliterans and bronchiolitis obliterans organising pneumonia by the absence of intraluminal granulation tissue plugs, and from the obliterative bronchiolitis of rheumatoid disease and diffuse peribronchiolitis on clinical grounds. Although often striking, this lesion does not represent a clinico-pathological entity, and may occur in the distal lung in association with a number of different diseases. "Small airways disease" is often used by clinicians in a functional context, and may lead to confusion. It is suggested that "chronic transmural bronchiolitis" is a more appropriate term.

(F Clin Pathol 1992;45:993-998)
Although asthma, chronic bronchitis and emphysema, bronchiectasis, and cystic fibrosis are the commonest causes of obstructive lung disease, disorders of smaller airways may lead to similar clinical and physiological changes. These conditions have been classified by Kindt et al as bronchiolitis obliterans, bronchiolitis obliterans organising pneumonia (BOOP), diffuse panbronchiolitis and "small airways disease". " Bronchiolar inflammation also occurs in graft-versus-host disease, ${ }^{2}$ connective tissue disorders, ${ }^{3}$ pulmonary and cardio-pulmonary transplantation, ${ }^{24} \mathrm{~T}$-cell leukaemia, ${ }^{5}$ ulcerative colitis $^{6}$ and human immunodeficiency virus (HIV) infection. ${ }^{7}$ Xanthomatous bronchiolitis obliterans ${ }^{8}$ and follicular bronchitis and bronchiolitis ${ }^{9}$ are also recognised.

"Small airways disease" is a somewhat ill defined chronic inflammatory condition of bronchioles and distal bronchi, first described in 1971 by Macklem et al. ${ }^{10}$ In a more recent study 11 of 16 patients with bronchiolar disease had biopsy specimens changes akin to those reported by Macklem's group. ${ }^{1}$ In this paper we report a further nine patients, and suggest that "chronic transmural bronchiolitis" is a more appropriate term.

\section{Methods}

In each case sections and paraffin wax blocks of the open lung biopsy specimens were available, together with the clinical notes. Sections were stained with haematoxylin and eosin, and by the elastic van Gieson method. Measurements of lung function were obtained from the clinical records. These included forced expiratory volume in one second (FEV1) and forced vital capacity (FVC), FEV$1: F V C$ ratio, total lung capacity (TLC), residual volume (RV) and recordings of maximal expiratory and inspiratory flow-volume loops together with diffusing capacity for carbon monoxide corrected for alveolar volume (KCO). Lung functions were expressed as a percentage of the predicted values. ${ }^{11}$

The clinical and radiological details of the nine patients are summarised in table 1 . Case 1 had had bronchiolitis as a neonate and had spent several weeks in an oxygen tent. Case 2 had been diagnosed as having stage IIa Hodgkin's disease three months before presentation, and developed a series of respiratory infections after starting a course of chemotherapy (mustine, vincristine, procarbazine and prednisolone) and radiotherapy. Case 3 had been treated with salazopyrin, tiaprofenic acid, dihy-

Correspondence to: Dr C W Edwards 
Table 1 Clinical details

\begin{tabular}{|c|c|c|c|c|c|}
\hline Case No & Age and sex & Smoking & Presenting symptoms & Clinical findings & Chest radiograph \\
\hline 1 & F32 & 20/day & Asthma $7 \mathrm{y}$, dyspnoea, dry cough, wheeze & Bilateral wheeze & Normal \\
\hline 2 & F 34 & $20 /$ day & $\begin{array}{l}\text { Hodgkin's disease, dyspnoea, dry cough, fever, } \\
\text { arthralgia } 3 \text { months }\end{array}$ & Basal crackles, clubbing & Basal shadows \\
\hline 3 & F40 & Non-smoker & $\begin{array}{l}\text { Sicca syndrome } 17 \mathrm{y} \text {, polyarthropathy, dyspnoea, } \\
\text { dry cough } 18 \text { months }\end{array}$ & Normal & Normal \\
\hline 4 & F42 & Non-smoker & $\begin{array}{l}\text { Dyspnoea, malaise, arthralgia, pyrexia and rigors, } 8 \\
\text { months }\end{array}$ & $\begin{array}{l}\text { Basal crackles, splinter haem- } \\
\text { orrhages }\end{array}$ & Basal shadows \\
\hline $\begin{array}{l}5 \\
6\end{array}$ & $\begin{array}{l}\text { F51 } \\
\text { F63 }\end{array}$ & $\begin{array}{l}20 / \text { day } \\
20 / \text { day }\end{array}$ & $\begin{array}{l}\text { Dyspnoea, productive cough } 15 \text { y } \\
\text { Dyspnoea, productive cough } 12 \text { months. Anorexia, } \\
\text { weight loss }\end{array}$ & $\begin{array}{l}\text { Basal crackles, hepatomegaly } \\
\text { Normal }\end{array}$ & $\begin{array}{l}\text { Diffuse pulmonary shadows } \\
\text { Right mid and lower zone } \\
\text { fibrosis. Apical fibrosis }\end{array}$ \\
\hline 7 & F66 & Non-smoker & Paroxysmal productive cough 4 y & Fine crackles, wheeze & $\begin{array}{l}\text { Soft micronodular shadows, } \\
\text { left mid zone }\end{array}$ \\
\hline 8 & M42 & $\begin{array}{r}\text { Ex-smoker } \\
(4 \text { years })\end{array}$ & $\begin{array}{l}\text { Asthma } 7 \text { years. Dyspnoea paroxysmal productive } \\
\text { cough. Occasional haemoptysis } 4 \text { y }\end{array}$ & Basal crackles & Bilateral basal shadowing \\
\hline 9 & M45 & Ex-smoker & $\begin{array}{l}\text { Dyspnoea, productive cough, malaise, myalgia } 4 \text { y. } \\
\text { Yellow nail syndrome }\end{array}$ & Normal & Left basal shadowing \\
\hline
\end{tabular}

drocodeine and paracetamol: she had never received gold or penicillamine. Case 5 dated her symptoms from a pneumonic episode 15 years previously. Case 6 had been treated for tuberculosis on the basis of the radiological findings. Case 7 had had pleurisy 12 years before presentation, but had only been symptomatic for four years. None of the other patients mentioned any antecedent respiratory infection, and all denied contact with allergens or birds.

Pulmonary function tests and the results of laboratory investigations are summarised in tables 2 and 3, respectively. In most cases there was evidence of airflow obstruction, which was largely irreversible. The FEV1 was reduced in cases $1,4,5,6$ and 8 , and there was an associated reduction in FEV 1:FEV ratio below $70 \%$ in cases 1,5 , and 8 . TLC varied from $61-116 \%$ of the predicted value, indicating that hyperinflation was not a feature. Residual volume was high in cases $1,3,5,6,7$ and 8 , this being reflected in the increased RV:TLC ratio in the same subjects. Case 4 was quite different in that she had the features of a

Table 2 Respiratory function tests (All values \% predicted)

\begin{tabular}{|c|c|c|c|c|c|c|c|c|c|}
\hline Case No & 1 & 2 & 3 & 4 & 5 & 6 & 7 & 8 & 9 \\
\hline $\begin{array}{l}\text { FEV1 } \\
\text { FVC } \\
\text { FEV1/FVC } \\
\text { TLC } \\
\text { RV } \\
\text { RV/TLC } \\
\text { KCO }\end{array}$ & $\begin{array}{r}37 \\
71 \\
54 \\
104 \\
190 \\
183 \\
78\end{array}$ & & $\begin{array}{r}116 \\
179 \\
154 \\
71\end{array}$ & $\begin{array}{r}62 \\
62 \\
97 \\
61 \\
61 \\
100 \\
72\end{array}$ & $\begin{array}{r}22 \\
41 \\
54 \\
92 \\
185 \\
200 \\
114\end{array}$ & $\begin{array}{r}41 \\
62 \\
72 \\
84 \\
150 \\
165 \\
75\end{array}$ & $\begin{array}{r}81 \\
88 \\
100 \\
107 \\
141 \\
134 \\
84\end{array}$ & $\begin{array}{r}59 \\
80 \\
21 \\
100 \\
154 \\
154 \\
85\end{array}$ & $\begin{array}{l}85 \\
89 \\
88 \\
87 \\
77 \\
33 \\
91\end{array}$ \\
\hline
\end{tabular}

Table 3 Laboratory investigations

\begin{tabular}{|c|c|c|c|c|}
\hline Serum protein & Autoantibodies & Precipitin & Other & Sputum bacteriology \\
\hline 1 Normal & ANA negative & N/A & & $H$ influenzae \\
\hline 2 Low IgA & $\begin{array}{l}\text { ANA, RA latex, Rose Waaler } \\
\text { negative }\end{array}$ & Aspergillus negative & Pancytopenia & $\begin{array}{l}H \text { influenzae, Klebsiella } \\
\text { species, } S \text { aureus }\end{array}$ \\
\hline 3 Normal & $\begin{array}{l}\text { ANA, RA latex, Rose Waaler } \\
\text { negative }\end{array}$ & N/A & ESR $20 \mathrm{~mm} / \mathrm{h}$ & Normal flora \\
\hline 4 Raised IgM & $\begin{array}{l}\text { ANA negative; RA latex, Rose } \\
\text { Waaer, IgMab positive }\end{array}$ & N/A & $\begin{array}{l}\text { Iron deficiency anaemia. } \\
\text { Hepatitis B negative }\end{array}$ & Normal flora \\
\hline 5 Slightly raised IgM, IgG & $\begin{array}{l}\text { ANA positive; RA latex, } \\
\text { DNAab negative }\end{array}$ & $\begin{array}{l}\text { Aspergillus, pigeon, chicken } \\
\text { negative; budgerigar weakly } \\
\text { positive }\end{array}$ & $\begin{array}{l}\text { Hepatitis B negative } \\
\text { Hepatitis A positive }\end{array}$ & Normal flora \\
\hline $\begin{array}{l}6 \text { Normal } \\
7 \text { Raised IgG }\end{array}$ & $\begin{array}{l}\text { N/A } \\
\text { ANA, RA latex negative }\end{array}$ & $\begin{array}{l}\text { N/A } \\
\text { Aspergillus positive }\end{array}$ & $\begin{array}{l}\text { N/A } \\
\text { Raised EST, low serum iron. } \\
\quad \text { Thyroxine } 9 \cdot 1 \text {, TSH } 7 \cdot 6\end{array}$ & $\begin{array}{l}\text { Normal flora } \\
\text { Normal flora }\end{array}$ \\
\hline 8 Raised IgG, IgM, IgE, IgG, & N/A & $\begin{array}{l}\text { Pigeon positive } \\
\text { Aspergillus, budgerigar, chicken } \\
\text { negative }\end{array}$ & Raised orosomucoid & $S$ aureus \\
\hline 9 Normal & ANA, RA latex negative & 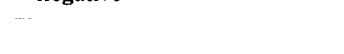 & $\begin{array}{l}\text { Raised C-reactive protein } \\
\text { I cukocytosis }\end{array}$ & Normal flora \\
\hline
\end{tabular}

restrictive ventilatory defect, with a low FEV1, FVC, and TLC. In case 9 the abnormality was less severe, but the pattern also favoured a restrictive ventilatory defect. Flow-volume loops in cases $1,7,8$ and 9 also showed changes compatible with dysfunction of small airways. Gas transfer was, in general, well preserved, the KCO ranging from $71-114 \%$ predicted. The lowest measurements were recorded in cases 1,3 , and 6 with airflow obstruction, and in case 6 with a restrictive defect. Pulmonary function testing was not carried out in case 2 .

Immunological investigations (table 3 ) failed to reveal any consistent abnormality. In case 2 immunity to tetanus, diphtheria, Escherichia coli and pneumococcal toxoids was impaired. In case 9 neutrophil function was normal, and there was a normal response to diphtheria and tetanus toxoids: there was no abnormality of T4:T8 function, or of lymphocyte response to mitogens and antigens. Serum IgA concentrations in case 8 were normal, and the normal quantity of $\operatorname{IgA}$ was present in a duodenal biopsy specimen. Other laboratory tests also failed to reveal any consistent pattern. The pancytopenia in case 2 was presumed to be the result of chemotherapy for Hodgkin's disease. Blood cultures in case 4 were persistently negative, despite the splinter haemorrhages.

In seven cases the disease was stabilised with various combinations of oral and inhaled bronchodilators, steroids, azathioprine and antibiotics (table 4). Two cases have been lost to follow up. Case 5 died in respiratory failure four years after presentation; permission for 
Table 4 Treatment and follow up

\begin{tabular}{ll}
\hline Treatment & Follow up \\
\hline 1 Steroids, bronchodilators, antibiotics, & Stable 3 years \\
azathioprine & Well 5 years later \\
2 Chemotherapy antibiotics & $\mathrm{N} / \mathrm{K}$ \\
$3 \mathrm{~N} / \mathrm{K}$ & Stable 2 years \\
4 Steroids, azathioprine & Died 4 years after presentation \\
5 Steroids, antibiotics, bronchodilators & $\mathrm{N} / \mathrm{K}$ \\
$6 \mathrm{~N} / \mathrm{K}$ & Improved after 1 year \\
7 Steroids, bronchodilators & Symptomatic improvement after three years \\
8 Steroids, bronchodilators & Improved after 2 years \\
9 Steroids, azathioprine & \\
\hline
\end{tabular}

8 Steroids, bronchodilator

necropsy was not obtained. Cases 4 and 8 have developed non-specific chronic gastritis confirmed by biopsy. A computed tomogram of case 8 showed changes compatible with bronchiolitis, and case 9 was shown to have bronchiectasis.

\section{Pathological findings}

The specimens submitted consisted of wedges of lung tissue varying from $2-6 \mathrm{~cm}$ across the major axis. In seven instances the specimen had been injected with formalin to distend the air spaces and avoid artefact due to postoperative collapse.

Although no abnormality was noted on gross examination of the specimens, in five cases centriacinar and sub-pleural mottling was apparent in the sections to the naked eye (fig 1). Microscopically, the walls of a variable proportion of terminal and proximal respiratory bronchioles were thickened and infiltrated by lymphocytes, plasma cells, and a few neutrophils (figs 2 and 3 ). The bronchiolar muscle was either disrupted or entirely destroyed. In two cases there were scattered, somewhat ill defined lymphoid follicles among the inflammatory cells (fig 2).
As the airways extended into the centre of the acini, where the inflammatory process was maximal, the lumen narrowed, often abruptly, breaking up into a series of smaller, distorted passages lined by cuboidal, non-ciliated epithelium (figs 2 and 3), reminiscent in some ways of the bile duct proliferation of chronic liver disease. The walls of adjacent alveoli were also thickened and infiltrated by chronic inflammatory cells: those towards the periphery were normal. The lumens of more proximal bronchioles were often dilated to a maximum diameter of $750 \mu \mathrm{m}$, were lined by apparently normal ciliated epithelium, and frequently contained a small quantity of muco-purulent material.

The inflammatory process often extended to the pleural surface from adjacent airways, and was associated with reactive change in the overlying mesothelium. Muscular pulmonary arteries also showed reactive change, with intimal fibrosis and medial hypertrophy (fig 3). The vasculature in the unaffected areas of the biopsy specimens was normal: there was never any evidence of pulmonary hypertension.

In two specimens (cases 2 and 7) there were scanty foci of organising exudate in alveolar spaces, and in one of these (case 2) a small quantity of exudate was present in a single bronchiole. The alveoli in four cases $(2,7,8$ and 9) showed some evidence of obstructive change, with an excess of intra-alveolar macrophages and a little proliferation of type II alveolar lining cells; in cases 2 and 8 there were neutrophils in occasional alveoli, and in case 9 the subpleural lymphatics showed the characteristic dilatation of yellow nail syndrome. The severest changes were present in case 8 , where fibrosis was extensive, and associated with early "honeycombing" (fig 4).
Figure 1 A whole section of an open lung biopsy specimen showing centriacinar mottling: case 7 bar: $5 \mathrm{~mm}$.

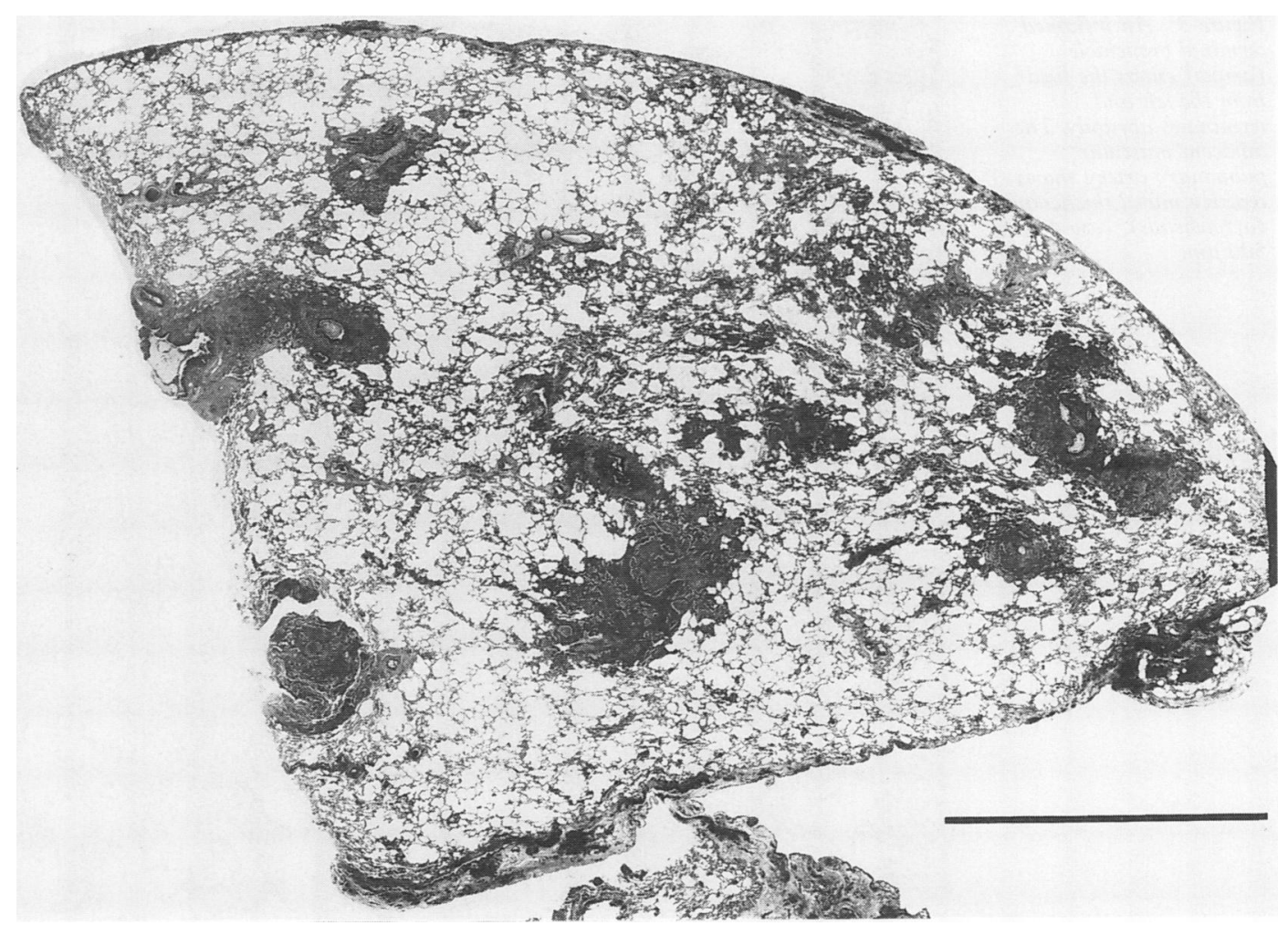


Figure 2 A terminal bronchiole (arrow), surrounded by fibrous tissue and inflammatory cells, runs into the field from the left, and breaks up abruptly into smaller airways. Scattered, ill defined aggregates of lymphocytic cells are present: case 9, bar: $500 \mu \mathrm{m}$.
Figure 3 An inflamed terminal bronchiole (arrow) enters the field from the left and terminates abruptly. The adjacent muscular pulmonary artery shows reactive mural thickening (arrowheads): case 4, bar: $500 \mu \mathrm{m}$.

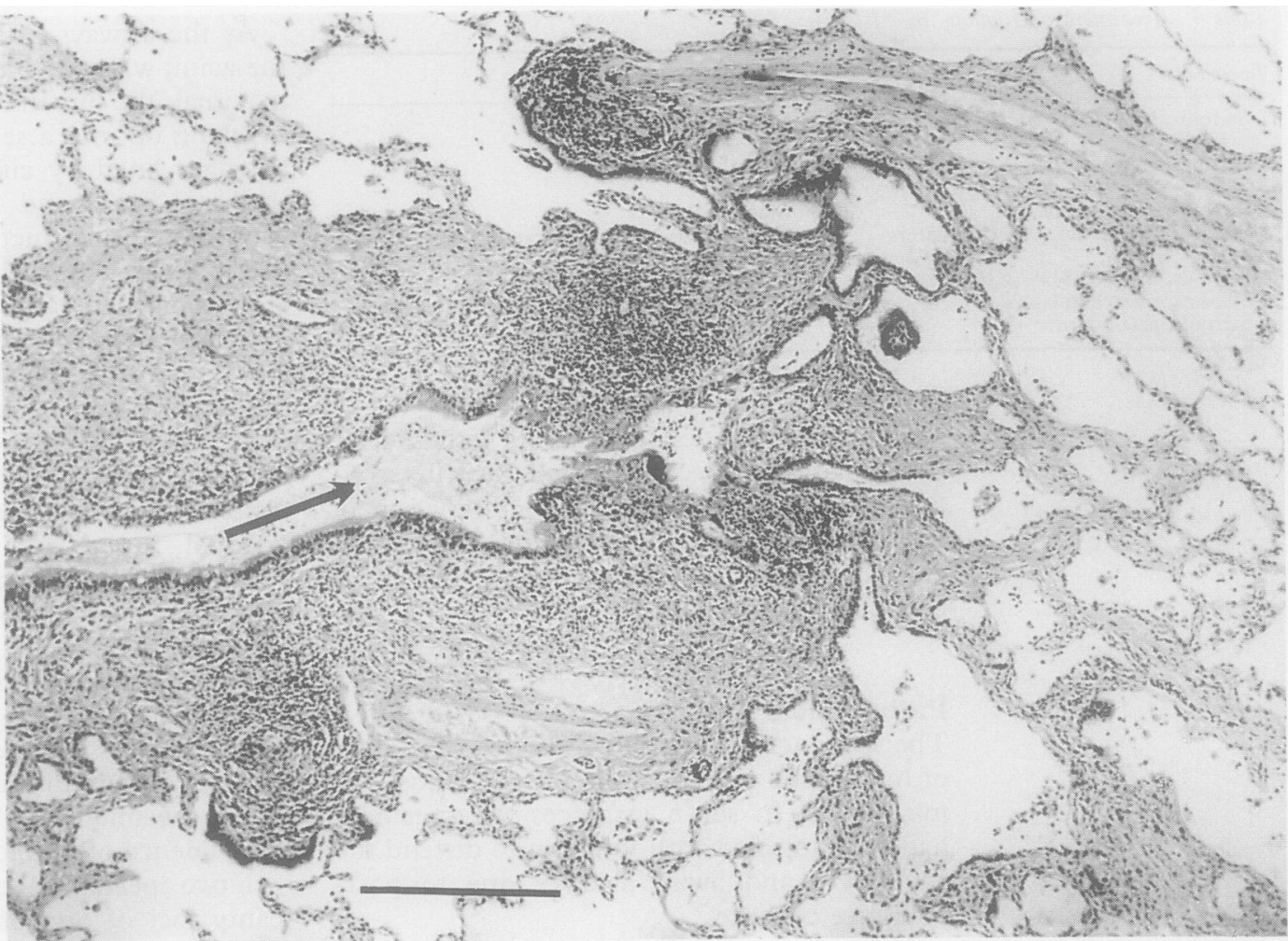

\section{Discussion}

The histological changes in the airways of this group of patients share certain features in common with diffuse panbronchiolitis, ${ }^{1213}$ the obliterative bronchiolitis of rheumatoid disease $^{314}$ and "small airways disease". ${ }^{10}$ Diffuse panbronchiolitis is a disorder of the "transitional zone" of the lung, which is located just distal to the terminal bronchiole, at the point where the air passage assumes a respiratory as well as a conductive function. ${ }^{12}$ Bronchiolar walls are infiltrated by histiocytes, lymphocytes, and plasma cells. The infiltrate extends into the adjacent pulmonary interstitium; proximally, terminal bronchioles dilate, and distally foamy cells accumulate in the peribronchiolar parenchyma. In necropsy tissue bronchiolar lumens are occluded by granulation tissue. ${ }^{13}$

Diffuse panbronchiolitis seems to be endemic in Japan, but has a low prevalence generally. ${ }^{12} \mathrm{~A}$ single European case in an Italian man was reported in $1990^{15}$ and further cases have been reported from North America. ${ }^{16}$ It

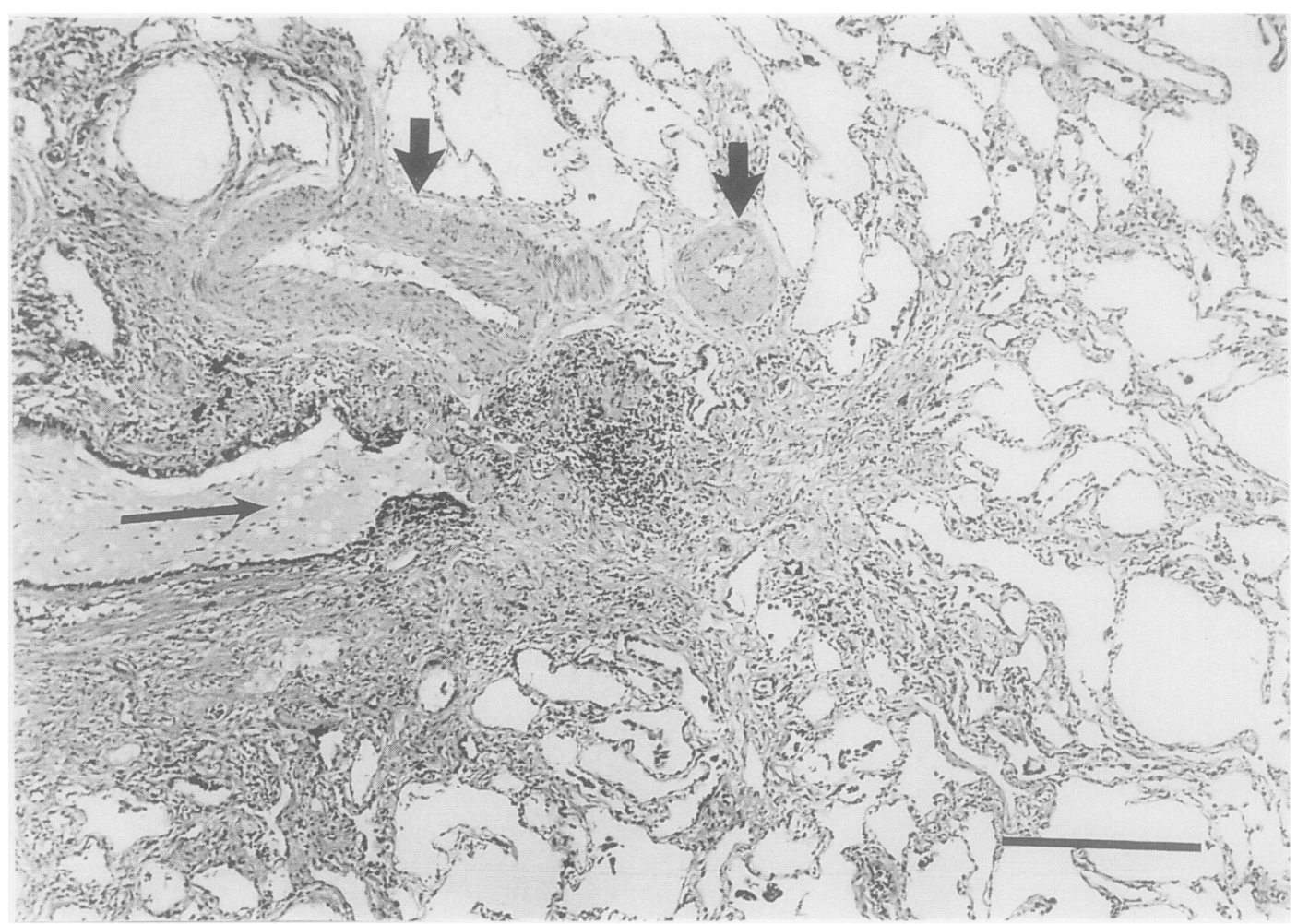


Figure 4 An area of early "honeycomb" change in case 8. Bar: $500 \mu m$.

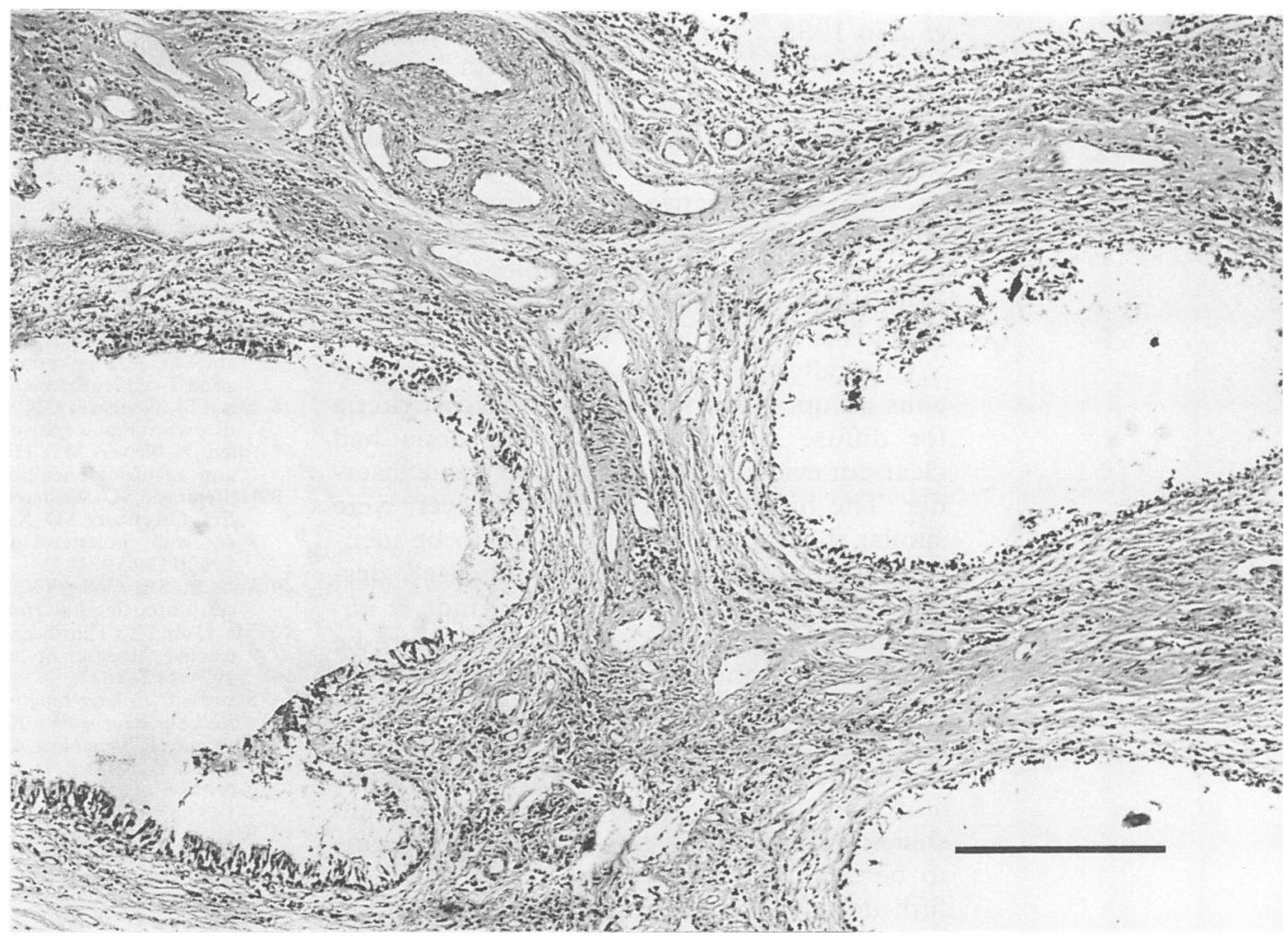

affects men more commonly than women and generally presents after the age of 40 : over $75 \%$ of patients have chronic sinusitis. Initially there is wheeze, cough, dyspnoea and hypoxaemia; later the sputum becomes purulent, and culture yields Pseudomonas aeruginosa in over $60 \%$ of cases. Pulmonary function tests show severe obstructive and slight restrictive defects. Bronchiolar lavage fluid contains a higher percentage of neutrophils and macrophages than in chronic bronchitic and normal subjects. ${ }^{17}$ Death usually results from respiratory failure.

The aetiology of diffuse panbronchiolitis is unknown. Smoking is not a factor; there is never a history of exposure to toxic gas or a preceding infection, or of chronic bronchitis, bronchiectasis, emphysema or asthma. Serum secretory IgA is high, but this is probably a non-specific expression of chronic airway inflammation. ${ }^{18} \mathrm{~A}$ chronic increase in cold haemagglutination titre has also been reported. ${ }^{19}$ In some cases there is a familial incidence. ${ }^{19}$ There seems to be an association with T-cell leukaemia, a disease cased by HTLV-1 which is frequently complicated by pulmonary infiltration and fibrosis. ${ }^{50-22}$ It has been suggested that HTLV-1 may affect the bronchioles as well as lymphocytes and the central nervous system. ${ }^{522}$

The obliterative bronchiolitis of rheumatoid arthritis and other connective tissue diseases $^{31423}$ is characterised by destruction of bronchiolar walls by a mixed inflammatory infiltrate. Luminal plugging by granulation tissue is not a feature ${ }^{14}$; the appearances conform to the less comon "constrictive" pattern of bronchiolitis as defined by Gosink et $a^{24}$ Lung function tests indicate airflow obstruction with air trapping and normal gas transfer. ${ }^{1425}$ Steroids are of little value, and the prognosis is poor. The pathogenesis is uncer- tain; penicillamine has been proposed as a factor, but its exact role is uncertain. ${ }^{2627}$

The concept of small airways disease was proposed by Macklem et al, ${ }^{10}$ who described a series of seven patients with chronic obstructive disease of small airways, but with no evidence of severe or extensive emphysema. Three were found to have bronchiectasis at necropsy, and two others were thought to have bronchiectasis, although this was never proved. Bronchiolar inflammation and mucous plugging were features in all cases, the important point being that it was more extensive than the bronchiectasis itself. A somewhat similar heterogeneous group of 16 patients with small airway lesions was reported more recently. ${ }^{1}$ In five the biopsy specimens showed the features of bronchiolitis obliterans. In the remainder bronchiolar inflammation without obliteration was the most consistent finding; in three the inflammatory process had spread to the interstitium. Overall, there was a severe, irreversible obstructive defect and occasionally a restrictive defect, with a high percentage (greater than $25 \%$ ) of neutrophils in bronchoalveolar lavage fluid.

In bronchiolitis obliterans, bronchioles are occluded by granulation tissue, and later replaced by fibrous tissue. Alveoli are not affected. This type of lesion occurs in marrow or heart-lung transplant recipients, ${ }^{2728}$ in patients with rheumatoid arthritis who may or may not be receiving gold or pencillamine treatment, other collagen diseases, and after viral infections or inhalation of toxic fumes. ${ }^{25}$ Some cases seem to be idiopathic. A somewhat similar condition affecting larger bronchi has been described in Stevens-Johnson syndrome. $^{2930}$

The entity now generally referred to as BOOP, following a report of 57 cases by Epler 
et al in $1985,{ }^{31}$ was first described by Davison et al in $1983,{ }^{32}$ who used the term "cryptogenic organising pneumonitis". This condition, which may be idiopathic or associated with exposure to fumes, drugs, or an infection, or with a connective tissue disorder ${ }^{25}$ is characterised by proliferation of granulation tissue alveoli as well as bronchioles ("burgeons conjunctifs" or Masson bodies). Response to steroids is usually favourable. ${ }^{25} 33$

Clinically, our patients are also a heterogeneous group. None fulfilled the clinical criteria for diffuse panbronchiolitis, and none had clear-cut evidence of a connective tissue disorder. The histological changes, however, were similar throughout, and appeared to be identical with the "small airways disease" described by Macklem et $a l^{10}$ and Kindt et al. ${ }^{1}$ "Small airways disease" therefore seems to be non-specific, and may arise as a result of different insults. It does not represent a distinct and definable clinico-pathological entity.

Despite the disparate clinical backgrounds, and non-specific histology, our patients do share certain features. This type of lesion seems to be commoner in women in the fourth or fifth decade of life. Presenting symptoms are cough (which may be paroxysmal), dyspnoea and wheeze, frequently associated with myalgia or arthralgia. On auscultation there are basal crackles, and opacities, usually basally situated, are seen on chest radiographs. In some cases there may be no radiological abnormality. Respiratory function tests reveal a predominantly obstructive ventilatory defect with little hyperinflation but considerable gas trapping, similar to that described in a clinical series of patients with disease of small airways by Turton et al. ${ }^{34}$ The airflow obstruction is largely irreversible, and the RV and RV:TLC values indicated gas trapping at the level expected in emphysema, but without the corresponding increase in lung volume. There is no gross impairment of gas transfer. Laboratory tests are unhelpful, and serological investigations for connective tissue disease tend to be negative or inconclusive. Although there may be a history of smoking, the changes are more severe than those described in cigaratte smokers. ${ }^{35}$ The disease process may be stabilised with bronchodilators alone, but steroids or azathioprine may also be needed. The nature of the changes, however, suggests that complete return to normal morphology and function is unlikely to occur.

When reporting biopsy material, this type of lesion must be distinguished from bronchiolitis obliterans and BOOP, and from other more specific conditions such as diffuse panbronchiolitis and the bronchiolitis of rheumatoid arthritis. The term "small airways disease" is imprecise, and may also lead to confusion because it is often used by clinicians in a physiological rather than a morphological context. We suggest that "chronic transmural broncholitis" is a more appropriate designation-adding the caveat that it is a histological change, and not a clinico-pathological entity. Its presence in biopsy material should signal the need for further investigation.
1 Kindt GC, Weiland JE, Davis WB, Gadek JE, Dorinsky PM Bronchiolitis in adults. A reversible cause of airway obstruction associated with airway neutrophils and neutrophil products. Am Rev Respir Dis 1989;140:483-92.

2 Epler GR. Bronchiolitis obliterans and airways obstruction associated with graft-versus-host-disease. Clin Chest Med 1988;9:551-6.

3 Hakala M, Pääkko P, Sutinen S, Huhti E, Koivisto O, Tarkka M. Association of bronchiolitis with connective tissue disorders. Am Rheum Dis 1986;45:656-62.

4 Yousem SA, Paradis IL, Dauber JH, Griffith BP. Efficacy of transbronchial lung biopsy in the diagnosis of brontransbronchial lung biopsy in the diagnosis of bron-
chiolitis obliterans in heart-lung transplant recipients. Transplantation 1989;47:893-5.

5 Ono K, ShimamotoY, Matsuzaki M, et al. Diffuse panbronchiolitis as a pulmonary complication in patients with adult T-cell leukaemia. Am $\mathcal{F}$ Hematol 1989;30:86-90.

6 Desai SJ, Gephardt GN, Stoller JK. Diffuse panbronchiolitis preceding ulcerative colitis. Chest 1989;95:1342-4.

7 Allen JN, Wewers MD. HIV-associated bronchiolitis obliterans organizing pneumonia. Chest 1989;96:197-8.

8 Heffelfinger SC, Weilbaecher DG, Lawrence EG, Johnson EH, Greenberg SD. Xanthomatous bronchiolitis obliterans with cholesterol pneumonia. Arch Pathol Lab Med 1988;112:650-3.

9 Yousem SA, Colby TV, Carrington CB. Follicular bronchitis/bronchiolitis. Hum Pathol 1985;16:700-6.

10 Macklem PT, Thurlbeck WM, Fraser RG. Chronic obstructive disease of small airways. Ann Intern Med 1971;74:167-77.

11 Standardised lung function testing. Working Party Report. Bull Eur Physiopathol Respir 1983;19(suppl 5):1-95.

12 Homma H, Yamanaka A, Tanimoto S, Tamura M, Chijimatsu Y, Kira S, Izumi T. Diffuse panbronchiolitis. A disease of the transitional zone of the lung. Chest 1983;83:63-9.

13 Kitaichi M, Nishimura K, Izumi T. Diffuse Panbronchiolitis. In: Sharma OP, ed. Lung disease in the tropics. New York: Marcel Dekker, 1991:479-509.

14 Geddes DM, Corrin B, Brewerton DA, Davies RJ, TurnerWarwick M. Progressive airway obliteration in adults and its association with rheumatoid disease. $Q f$ Med 1977;46:427-44

15 PlettiV, Patelli M, Poletti G, BertantiT, Spiga L. Diffuse panbronchiolitis observed in an Italian. Chest 1990;98:515-6.

16 Randhawa P, Hoagland MH, Yousem SA. Diffuse panbronchiolitis in North America. Report of three cases and review of the literature. Am ₹ Surg Pathol 1991;15:43-7.

17 Ichikawa Y, Koga H, Tanaka M, Nakamura M, Tokunaga H, Kaji $M$. Neutrophilia in bronchiolar lavage fluid of diffuse panbronchiolitis. Chest 1990;98:917-23.

18 Noda Y, Tasuoka S, Tani K, Ogura T, Ogawara M, Kitatani F. Secretory IgA (S-IgA) levels in sera from patients with diffuse panbronchiolitis. $\mathcal{F} p n \mathcal{F}$ Med 1989;28:189-95.

19 Sugiyama Y, Kudoh S, Maeda H, Suzaki H, Takaku F. Analysis of HLA antigens in patients with diffuse panAnalysis of HLA antigens in patients with diffuse pan-
bronchiolitis. Am Rev Respir Dis 1990;141:1459-62.

20 Kimura I, Ohnoshi T, Tsubota T, et al. Appearances of ATL cell and ATLA related reactions in diffuse panbronchiolitis. Ipn $\mathcal{F}$ Thorac Dis 1987;25:240-4.

21 Yoshioka $R$, Yamaguchi $K$, Yoshinaga $T$, Takatsuki $K$. Pulmonary complications in patients with adult T-cell leukaemia. Cancer 1985;55:2391-4.

22 Osame M, Usuku K, Izumo S, et al. HTLV-I associated myelopathy, a new clinical entity. Lancet 1986;i:1031-2.

3 Herzog C, Miller R, Hoidal J. Bronchiolitis and rheumatoid arthritis. Am Rev Respir Dis 1981;124:636-9.

24 Gosink BB, Friedman PJ, Liebow AA. Bronchiolitis obliterans. Roengenologic-pathologic correlation. Am $\mathcal{F}$ Roentgenol 1973;117:816-32.

25 Woodhead MA, Du Bois RM. Bronchiolitis obliterans, cryptogenic organising pneumonitis and BOOP. Respir Med 1991;85:177-8.

26 Murphy KC, Atkins CJ, Offer RC, Hugg JC, Stein HB. Obliterative bronchiolitis in two rheumatoid patients treated with penicillamine. Arthritis Rheum 1981; 24:557-60.

27 King TE Jr. Bronchiolitis obliterans. Lung 1989; 167:69-93.

28 Sullivan KM, Shulman KM. Chronic graft-versus-host disease, obliterative bronchiolitis and graft-versusleukaemia effect: case histories. Transplant Proc 1989; 21(3 suppl 1):51-62.

29 Edwards C, Penny M, Newman J. Mycoplasma pneumonia, Stevens-Johnson syndrome and chronic obstructive bronStevens-Johnson syndrome and
chitis. Thorax 1983;38:867-9.

30 Tsunoda N, Iwanaga T, Saito T, Kitamura S, Saito K Rapidly progressive bronchiolitis obliterans associated Rapidly progressive bronchiolitis obliterans associated
with Stevens-Johnson syndrome. Chest 1990;98:243-5.

31 Epler GR, Colby TV, McLough TC, Carrington CB, Gaensler EA. Bronchioloitis obliterans organizing pneuGaensler EA. Bronchioloitis obliterans
monia. $N$ Engl $f$ Med 1985;312:152-8.

32 Davison AG, Heard BE, McAllister WAC, Turner-Warwick $\mathrm{MEH}$. Cryptogenic organising pneumonitis. $Q \mathcal{F} \mathrm{Med}$ 1983;52:382-94.

33 Cordier JF, Loire R, Brune J. Idiopathic bronchiolitis obliterans organising pnemonia. Definition of characteristic clinical profiles in a series of 16 patients. Chest 1989;96:999-1004.

34 Turton CW, Williams G, Green M. Cryptogenic obliterative bronchiolitis in adults. Thorax 1981;36:805-10.

35 Yousem SA, Colby TV, Gaensler EA. Respiratory bronchiolitis-associated interstitial lung disease and its relationship to desquamative interstitial pneumonia. Mayo Clin Proc 1989;64:1373-80. 